\title{
Article \\ Effects of NIR Reflective Film as a High Tunnel-Covering Material on Fruit Cracking and Biomass Production of Tomatoes
}

\author{
Hiroko Yamaura ${ }^{1}$ (), Shinichi Furuyama ${ }^{2}$, Nobuo Takano ${ }^{1}$, Yuka Nakano ${ }^{1}$, Keiichi Kanno ${ }^{1}$, Takashi Ando ${ }^{3}$, \\ Ichiro Amasaki ${ }^{3}$, Yukie Watanabe ${ }^{3}$, Yasunaga Iwasaki ${ }^{1,4}$ and Masahide Isozaki ${ }^{1, *}$ \\ 1 Institute of Vegetable and Floriculture Science, National Agricultural and Food Research Organization (NARO), \\ Tsukuba 305-8519, Japan; yamaurah090@affrc.go.jp (H.Y.); ampf.ishigaki5050@gmail.com (N.T.); \\ yuka88@affrc.go.jp (Y.N.); k.kanno@affrc.go.jp (K.K.); iwasakiy@meiji.ac.jp (Y.I.) \\ 2 Kamikawa Agricultural Experiment Station, Hokkaido Research Organization (HRO), Pippu 078-0397, Japan; \\ furuyama-shinichi@hro.or.jp \\ 3 Fujifilm Corporation, Tokyo 107-0052, Japan; takashi.ando@fujifilm.com (T.A.); \\ ichiro.amasaki@fujifilm.com (I.A.); yukie.a.watanabe@fujifilm.com (Y.W.) \\ 4 Department of Agriculture, Meiji University, Kawasaki 214-8571, Japan \\ * Correspondence: isozakim915@affrc.go.jp
}

Citation: Yamaura, H.; Furuyama, S.; Takano, N.; Nakano, Y.; Kanno, K.;

Ando, T.; Amasaki, I.; Watanabe, Y.;

Iwasaki, Y.; Isozaki, M. Effects of NIR

Reflective Film as a High

Tunnel-Covering Material on Fruit

Cracking and Biomass Production of

Tomatoes. Horticulturae 2022, 8, 51.

https://doi.org/10.3390/

horticulturae 8010051

Academic Editors: Xiaohui $\mathrm{Hu}$

Shiwei Song and Xun Li

Received: 1 December 2021

Accepted: 2 January 2022

Published: 6 January 2022

Publisher's Note: MDPI stays neutral with regard to jurisdictional claims in published maps and institutional affiliations.

Copyright: (C) 2022 by the authors. Licensee MDPI, Basel, Switzerland. This article is an open access article distributed under the terms and conditions of the Creative Commons Attribution (CC BY) license (https:// creativecommons.org/licenses/by/ $4.0 /)$.

\begin{abstract}
Tomatoes require higher irradiance, although the incidence of physiological disorders in fruit increases at high temperatures. Near-infrared $(800-2500 \mathrm{~nm})$ (NIR) reflective materials are effective tools to suppress rising air temperatures in greenhouses. We examined the physiological and morphological changes in tomato growth and fruit quality when grown in a high tunnel covered with NIR reflective film (NR) and in another covered with polyolefin film (PO; control). There was no relationship between the fruit cracking rate and mean daytime temperature under NR. The fruit temperature at the same truss was lower and the increase in air temperature was slow under NR. Fruit dry matter (DM) content under NR was also significantly decreased. These findings suggest that the reduction in fruit cracking under NR results from a decrease in fruit DM content as a consequence of lower fruit temperature and a decrease in total DM (TDM). Total fruit yield did not differ, whereas TDM was significantly decreased under NR. This was considered to result from a lower transmitted photosynthetic photon flux density (400-700 nm) (PPFD) and LAI, and lower photosynthetic capacity in single leaves because of a decrease in both total nitrogen and chlorophyll content. We conclude that NR film reduces fruit cracking in exchange for a slight reduction in TDM.
\end{abstract}

Keywords: net assimilation rate (NAR); leaf nitrogen; fruit temperature; dry matter; chlorophyll

\section{Introduction}

Tomatoes are one of the most commercially valuable vegetables in the world. In recent years, the demand for tomatoes has increased in Asia and their production and cultivated area have been rising [1]. Tomatoes require high irradiance [2]; however, the air temperature in greenhouses tends to increase to levels inappropriate for tomato growth, when the amount of solar radiation entering the greenhouse increases in high-temperature regions and seasonally. As a result, the incidence of physiological disorders in fruit, such as fruit cracking, yellow-shoulder fruits, and increased blossom-end rot, may cause a decrease in marketable fruit yield [3]. Therefore, it is necessary to develop material and management strategies for the greenhouse to improve fruit quality in high-temperature regions and seasons.

Near-infrared (800-2500 nm) (NIR) reflective materials can be an effective tool for growing tomatoes under such conditions. A simulation study of NIR-filtering materials, used to cover a greenhouse in the Netherlands, indicated that tomato production in the summer could increase by $8.6 \%$ because the air temperature inside the greenhouse would be lower by $2.0^{\circ} \mathrm{C}$ at noon and crop transpiration would also decrease [4]. In fact, air 
temperatures in a greenhouse with a NIR-filtering material could be reduced by up to $4.0^{\circ} \mathrm{C}$ in Thailand [5] and $3.0^{\circ} \mathrm{C}$ in Southern Spain [6] without reducing yields during the summer season. Stanghellini et al. [7] reported that the use of NIR reflective film reduced crop transpiration, increased the water use efficiency of rose crops, and maintained rose yields. Accordingly, it has been suggested that NIR reflective films can suppress increases in air temperature in greenhouses and reduce crop transpiration, which results in maintained crop yields, even at high temperatures.

Moreover, NIR reflective films are effective at improving fruit quality at high temperatures [8-10]. In fact, Nakayama et al. [10] reported that NIR reflective film reduced the rate of fruit cracking by $70 \%$ compared with controls in June, which is the month presenting the highest solar radiation. Fruit cracking is related to high air temperature, high solar radiation, the difference between daytime and nighttime temperatures, and fruit temperature [11-14]. Therefore, NIR reflective film reduces fruit cracking by suppressing the increase in air temperature in the greenhouse. Similarly, the NIR reflective film may also suppress the increase in fruit temperature. Blanchard and Runkle [15] reported that the temperatures of leaves and shoot-tips in cucumbers decreased under NIR-reflecting materials. Lobos et al. [16] also reported that grape bunches covered with shading nets with low NIR transmittance reduced fruit temperature and improved fruit quality. The occurrence of physiological disorders in fruit increase with higher fruit temperature in tomatoes [14]. Thus, lowering the fruit temperature can prevent fruit cracking. However, there have been no reports on the measurement of the fruit temperature of crops grown in greenhouses covered with NIR reflective film.

Similarly, there have been few case studies giving a detailed analysis of the effects of NIR-reflecting materials on whole-plant growth from morphological and physiological perspectives. Plants display an adaptive response to environmental changes in light and temperature, not only in individual leaves but also at the whole-plant level. For example, physiological responses at the individual leaf level include a decrease in chlorophyll (chl) content per fresh weight under high-temperature conditions [17] and an increase in the proteins involved in light-harvesting [18]. The $\mathrm{chl} \mathrm{a/b}$ ratio tends to increase but the chl content decreases under low light [19]. In addition to these physiological responses, tomatoes show morphological responses at the individual level. For example, the specific leaf area increases with rising daytime temperature [20] but decreases with high light intensity [21]. Similarly, the net assimilation rate (NAR) increases with increasing temperature [22], and the leaf area ratio increases in low light [23]. As described above, morphological changes at the individual whole-plant level are important for adapting to environmental changes, in addition to physiological changes at the individual leaf level.

NIR reflective films reduce NIR transmittance, the thermal factor that increases air temperature in the greenhouse. However, they may reduce the amount of light available for photosynthesis of the wavelengths from 400 to $700 \mathrm{~nm}$ [24]. It is important to analyze the effects of NIR reflective materials on dry matter (DM) production in tomatoes and the morphological and physiological aspects at the whole-plant level, when considering the possibility of expanding the seasons using NIR reflective film in tropical and sub-tropical regions, including Asia.

Therefore, the purpose of this study was to identify the causes of reduced fruit cracking during the summer and autumn and the morphological and physiological changes in plant growth on total yield and fruit quality under NIR reflective film. We examined the microclimate during the daytime and fruit temperature in a high tunnel covered with NIR reflective film and analyzed the relationship with fruit cracking. Then, we analyzed a growth strategy for plants under NIR reflective film. Later in this paper, we will discuss improvements in fruit quality with respect to DM production and the high tunnel microclimate. 


\section{Materials and Methods}

\subsection{Plant Materials and Growing Condition PAR}

The experiments were conducted from 6 August to 6 November 2020 in two high tunnels (area, $112 \mathrm{~m}^{2}$; wire height, $2.5 \mathrm{~m}$ ) located at the National Agricultural and Food Research Organization, Japan $\left(36.0^{\circ} \mathrm{N}, 140.1^{\circ} \mathrm{E}\right)$. The roof cover of one high tunnel was NIR reflective film (NR) (thickness, 0.10 mm; MF-450; Fujifilm Co. Ltd., Tokyo, Japan) and the other was agricultural polyolefin film (PO) as a control (thickness, $0.15 \mathrm{~mm}$; Diastar; Mitsubishi Chemical Agri Dream Co., Ltd., Tokyo, Japan). NR transmits 0.71 in the photosynthetically active radiation (PAR) range $(400-700 \mathrm{~nm}), 0.39$ in the NIR range, and 0.31 in the ultraviolet (UV) range (300-400 nm). PO transmits 0.91 in the PAR range, 0.91 in the NIR range, and 0.68 in the UV range (Figure 1). The side covers of both high tunnels were made of PO (Tekinashi5, C.I. Kasei Co., Ltd., Tokyo, Japan). In each high tunnel, four cultivation beds were arranged in a north-south direction, with a distance between beds of $1.6 \mathrm{~m}$.

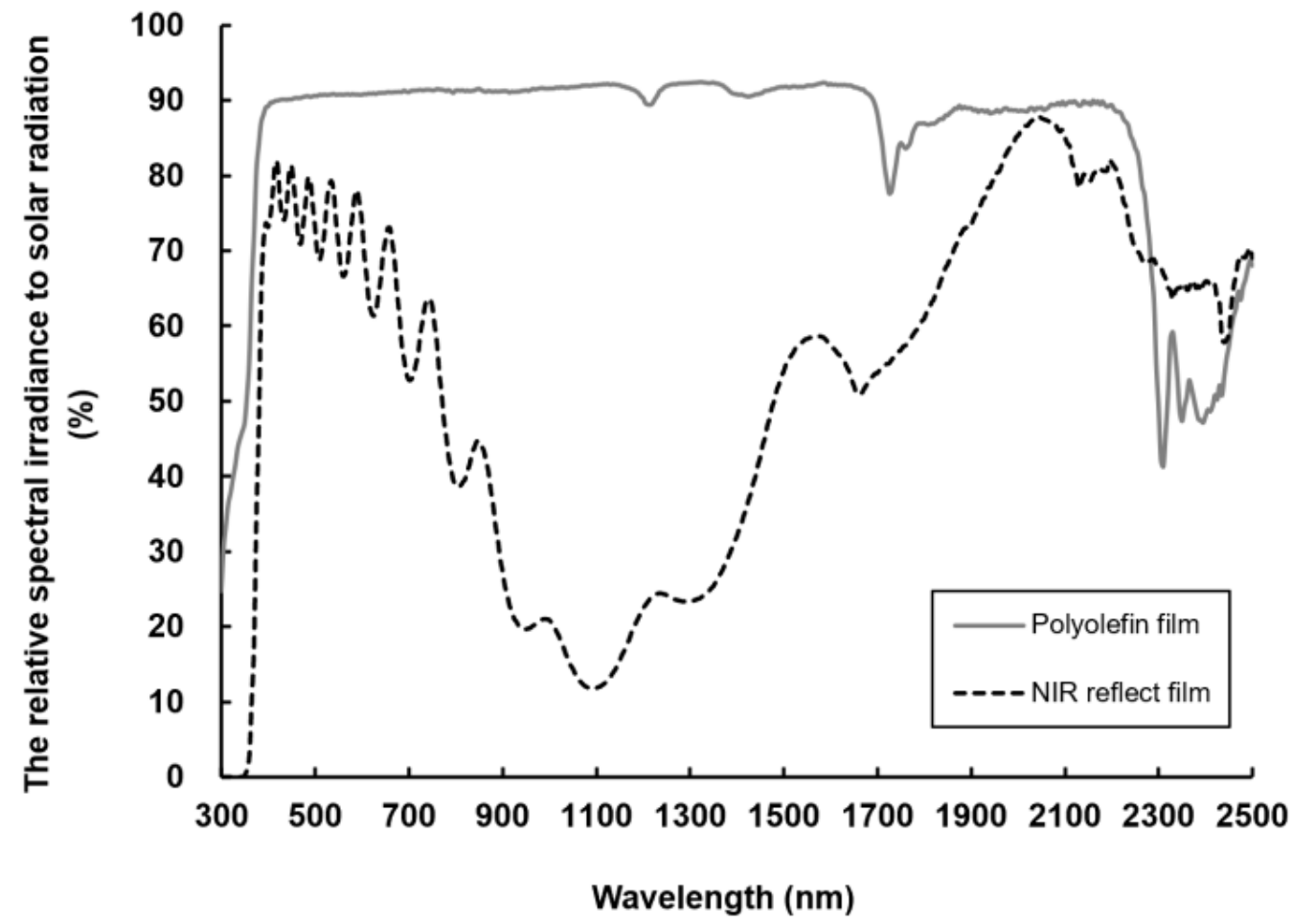

Figure 1. The relative spectral irradiance of polyolefin film (PO) and NIR reflective film (NR) to solar radiation in the present study.

Tomato seeds ("Momotaro Hope", Takii Co., Ltd., Kyoto, Japan) were sown into 72-cell plug trays with a commercial substrate (Tanebaido No.1, Sumitomo Forestry Landscaping Co., Ltd., Tokyo, Japan) on 6 July 2020 and germinated in the darkness for 3 days. Seedlings were grown in a temperature-controlled chamber equipped with fluorescent tubes (NAE Terrace, Mitsubishi Chemical Agri Dream Co., Ltd., Tokyo, Japan) for 1 week. The chamber was operated at $350 \mu \mathrm{mol} \mathrm{m} \mathrm{m}^{-2} \mathrm{~s}^{-1}$ photosynthetic photon flux density $(400-700 \mathrm{~nm})$ (PPFD), with a day/night temperature of $25^{\circ} \mathrm{C} / 18^{\circ} \mathrm{C}$ (daytime $16 \mathrm{~h}$ ), and $1000 \mathrm{ppm} \mathrm{CO}_{2}$ concentration. The seedlings were irrigated every day with a commercial nutrient solution (High Tempo; Mitsubishi Chemical Agri Dream Co., Ltd.; $9.7 \mathrm{mM} \mathrm{NO}_{3}^{-}, 5.9 \mathrm{mM} \mathrm{K}^{+}$, $2.6 \mathrm{mM} \mathrm{Ca}^{2+}, 0.9 \mathrm{mM} \mathrm{Mg}^{2+}, 2.3 \mathrm{mM} \mathrm{H}_{2} \mathrm{PO}_{4}, 0.9 \mathrm{mM} \mathrm{NH}_{4}{ }^{+}, 0.7 \mathrm{mM} \mathrm{SO}_{4}{ }^{2-}$ ) at an electrical conductivity (EC) of $1.5 \mathrm{dS} \mathrm{m}^{-1}$. The seedlings were then transplanted to rockwool cubes and arranged at a density of 27.8 plants $\mathrm{m}^{-2}$ in nursery high tunnels. They were supplied with a commercial nutrient solution (OAT House-SA; OAT Agrio Co., Ltd., Tokyo, Japan; 
$17.6 \mathrm{me} \cdot \mathrm{L}^{-1} \mathrm{NO}_{3}, 4.4 \mathrm{me} \cdot \mathrm{L}^{-1} \mathrm{P}, 10.2 \mathrm{me} \cdot \mathrm{L}^{-1} \mathrm{~K}, 8.2 \mathrm{me} \cdot \mathrm{L}^{-1} \mathrm{Ca}$, and $3.0 \mathrm{me} \cdot \mathrm{L}^{-1} \mathrm{Mg}$ at EC of $2.6 \mathrm{dS} \mathrm{m}^{-1}$ ), adjusted to an EC of $1.0 \mathrm{dS} \mathrm{m}^{-1}$.

On 6 August 2020, the seedlings were transplanted onto rockwool slabs in a cultivation bed at $0.125 \mathrm{~m}$ intervals (mean plant density, 5.0 plants $\mathrm{m}^{-2}$ ) under NR or PO. A 300-liter plastic tank for irrigation was prepared in each high tunnel. The concentration of OAT House-SA was homogenized in the tank, and it was gradually increased to an EC of $1.8 \mathrm{dS} \mathrm{m}^{-1}$ and adjusted to around $\mathrm{pH} 6.0$ using a fertilizer management system (PCE-11, CEM Corporation, Tokyo, Japan). The concentration of OAT House-SA was gradually increased to an EC of $1.8 \mathrm{dS} \mathrm{m}^{-1}$. The daily draining volume was approximately $20-30 \%$ of the total volume of the nutrient solution supplied, and the drainage was discarded. Fruit set was promoted by spraying the flowers with 2-methyl-4-chlorophenoxyacetic acid (Tomato Tone; ISK Bio-sciences K.K., Tokyo, Japan) twice a week. The number of fruits per truss was adjusted to four by pruning and the auxiliary buds were also pruned. At 43 days after transplanting (DAT), the plants were pinched out to generate two leaves above the fourth truss.

In the PO-covered high tunnel, a movable shading screen (Venus Rassell \#50, Koizumi Jute Mills Ltd., Kobe, Japan) was closed when the inside air temperature was above $35.0^{\circ} \mathrm{C}$, then opened when the air temperature was below $33.0^{\circ} \mathrm{C}$. This screen transmits $50 \%$ of the solar radiation. For both high tunnels, the night temperature was maintained by cooling from the day of transplanting to 37 DAT $\left(18-20^{\circ} \mathrm{C}\right)$ or by heating from 56 DAT onward $\left(15-22{ }^{\circ} \mathrm{C}\right)$. The side vents in both high tunnels were set to start to open at an inside air temperature of $20^{\circ} \mathrm{C}$ and to be fully open at $28^{\circ} \mathrm{C}$. A fog cooling system was operated when the external solar radiation was greater than $0.4-0.5 \mathrm{~kW} \mathrm{~m}^{-2}$ and the inside air temperature was above $28{ }^{\circ} \mathrm{C}$. From $44 \mathrm{DAT}, \mathrm{CO}_{2}$ fertilization was applied at $2.0 \mathrm{~g} \mathrm{~m}^{-2} \mathrm{~h}^{-1}$ at an external solar radiation level of $\geq 0.1 \mathrm{~kW}$. These operations were controlled by a ubiquitous environmental control system device (UECS-Pi, WaBit Co., Ltd., Fukuoka, Japan). This device also recorded air temperature, relative humidity, external solar radiation, and $\mathrm{CO}_{2}$ concentration every minute. The transmitted PPFD was calculated from the operation rate of the movable shading screen. First, a pyranometer (MS-602, EKO instrument Japan Inc., Tokyo, Japan) was set outside the high tunnels to confirm that there was no difference between the amount of solar radiation recorded per hour and the amount of solar radiation data per hour recorded by the Areological Observatory at Tateno $\left(36.1^{\circ} \mathrm{N}, 140.1^{\circ} \mathrm{E}\right)$ from the Japan Meteorological Agency (JMA) [25]. Secondly, the quantum sensors (LI-190, Li-Cor Inc., Lincoln, NE, USA) were also set inside each high tunnel to investigate the correlation between the amount of PPFD per hour and the amount of solar radiation data per hour from JMA. In this way, the coefficients of PPFD transmittance into each high tunnel were determined using the total solar radiation data from JMA.

\subsection{Destructive Measurements and Growth Analysis}

Initial total biomass and total leaf area were measured destructively in ten plants before transplanting on 6 August 2020. Twenty-four plants ( 8 replicates; three plants per replication) grown under NR or PO were also destructively harvested at 42 and 92 DAT. Leaves, stems, and fruits were separated, weighed to determine the fresh weight, dried at $105{ }^{\circ} \mathrm{C}$ for at least 3 days, and reweighed to determine the dry weight of each organ. Total leaf area was determined using an area meter (AAC-400, Hayashi Denko Co. Ltd., Tokyo, Japan). Crop growth rate (CGR; DM production per unit ground area per unit time) and net assimilation rate (NAR; DM production per unit leaf area per unit time) were calculated between the time points of the destructive measurements [26,27]. The leaf area index (LAI; leaf area per cultivated area) was calculated using the total leaf area by destructive measurement.

\subsection{Measurement of Temperature and Fruit Quality}

The number of mature fruits, as well as fresh and dry fruit weight, were measured twice a week from 48 DAT onwards. All fruits with cracks that were detectable by eye 
were counted as cracked. Marketable fruit yield was defined as the total fruit yield minus disordered fruits (cracking, blossom-end rot, or catface). Fruit temperature was measured on 28 September 2020 (54 DAT) from 1.40 p.m., and the measurements were completed within $10 \mathrm{~min}$. The fruit temperature was measured at the equatorial plane for all fruits in three randomly selected plants from the first to the fourth truss, using an infrared thermometer (IT-545, Horiba Ltd., Kyoto, Japan). Weather conditions did not change during the measurements.

\subsection{Determination of Chl and Total N per Leaf Area}

Two leaf disks ( $8 \mathrm{~mm}$ in diameter) from the leaves were punched and chl was extracted with dimethylformamide for $48 \mathrm{~h}$ in the dark. Chl content was determined as described by Porra et al. [28]. The remainder of the leaf was dried at $105^{\circ} \mathrm{C}$ for at least 3 days and total $\mathrm{N}$ content was measured with a CN analyzer (JM1000N, J-Science Lab Co., Ltd., Kyoto, Japan).

\subsection{Statistical analysis}

Destructive measurements, growth analysis, and fruit yield and quality were based on eight replicates. The chl and total $\mathrm{N}$ per leaf area were assessed using four replicates (one leaf per plant, four plants). To assess the statistical significance of the differences, all the data were analyzed using an independent Student's $t$-test with a level of significance of $p<0.05$, using Microsoft Excel for Microsoft 365 MSO.

A Pearson correlation between mean daytime ( 7 a.m. to 5 p.m.) air temperature and the rate of fruit cracking under each high tunnel was conducted using the $\mathrm{R}$ statistical software (version 4.1.1, https://www.R-project.org/, accessed on 7 October 2021). The flowering day was defined as the day when the cumulative daily mean air temperature reached approximately $1100{ }^{\circ} \mathrm{C}$ from the harvest date [29]. The mean daytime temperature from flowering to harvest was calculated and used as a variable. The rate of fruit cracking was also used as a variable. The values were calculated by the number of cracked fruits, divided by the total number of harvested fruits for each harvest date.

\section{Results}

\subsection{The Climate in High Tunnel}

The daily mean air temperature and cumulative PPFD during the experiments in each high tunnel are shown in Figure 2 (panels A and B, respectively). The daily mean air temperature throughout the growing periods was $23.1^{\circ} \mathrm{C}$ under $\mathrm{NR}$ and $23.4{ }^{\circ} \mathrm{C}$ under PO. In particular, from August to mid-September, the daily mean temperature under NR was lower than that under PO (Figure S1). The cumulative hours of air temperature above $28.0^{\circ} \mathrm{C}$ during the daytime ( 7 a.m. to 5 p.m.) and the ratio of each categorical temperature in cumulative hours under NR or PO are shown in Figure 3. Because the side vent was fully open, a fog cooling system was used when the inside air temperature was above $28.0^{\circ} \mathrm{C}$. Each instantaneous air temperature (recorded every minute) was categorized every 2.0 degrees. The cumulative hours of instantaneous temperatures above $28.0{ }^{\circ} \mathrm{C}$ were approximately $418 \mathrm{~h}$ under NR and approximately $448 \mathrm{~h}$ under PO. The ratio of cumulative hours of air temperature above $34.0^{\circ} \mathrm{C}$ to the cumulative hours of air temperature above $28.0{ }^{\circ} \mathrm{C}$ under $\mathrm{PO}$ was about 1.6 times the ratio of that under NR. The maximum air temperature was $38.3^{\circ} \mathrm{C}$ under $\mathrm{NR}$ and $39.6{ }^{\circ} \mathrm{C}$ under $\mathrm{PO}$ throughout the experiment. The ability of NIR reflective film to suppress the increase in air temperature has been reported $[4-6,30,31]$ and our data is consistent with these reports. The air temperature did not increase excessively because of a decrease in solar radiation from 17 DAT (23 August) (Figure 2B). Under PO, the rate of shading screen operation during the daytime was $51.4 \%$ in August, 2.4\% in September, and 1.6\% in October. Thus, the total transmitted PPFD was approximately $15.6 \%$ lower under NR compared with PO (1346.5 mol m${ }^{-2}$ experiment $^{-1}$ under NR and $1556.5 \mathrm{~mol} \mathrm{~m}^{-2}$ experiment $^{-1}$ under $\mathrm{PO}$ ). 

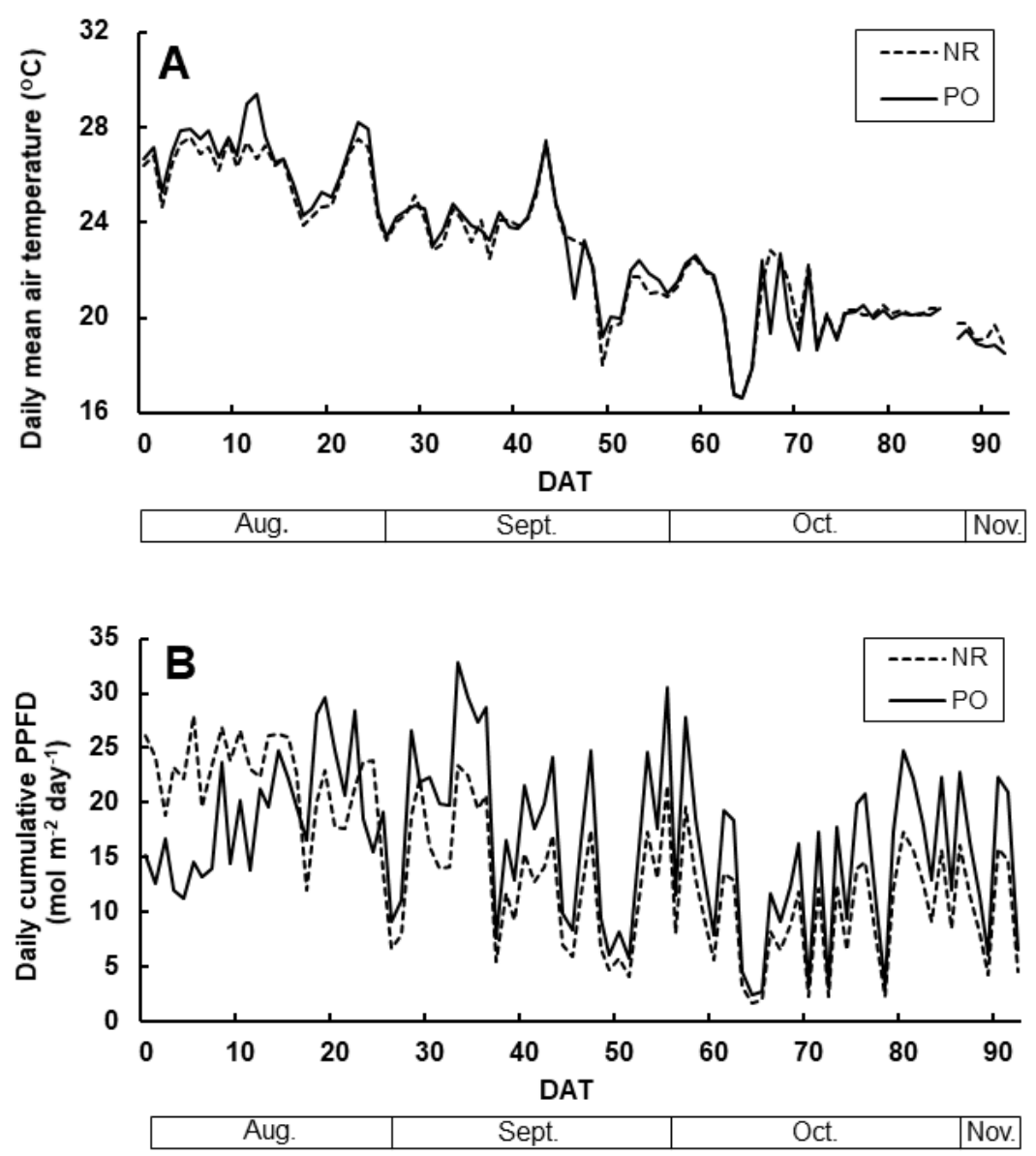

Figure 2. Daily mean air temperature (A) and daily cumulative PPFD (B) in each high tunnel. NR, NIR reflective film; PO, polyolefin film.

\begin{tabular}{|lll|}
\hline$\square 28 \sim 29.9$ & $\square 30 \sim 31.9$ & $\boxminus 32 \sim 33.9$ \\
$\square 34 \sim 35.9$ & $\square 36 \sim 37.9$ & $\square 38 \sim 39.9$ \\
\hline
\end{tabular}

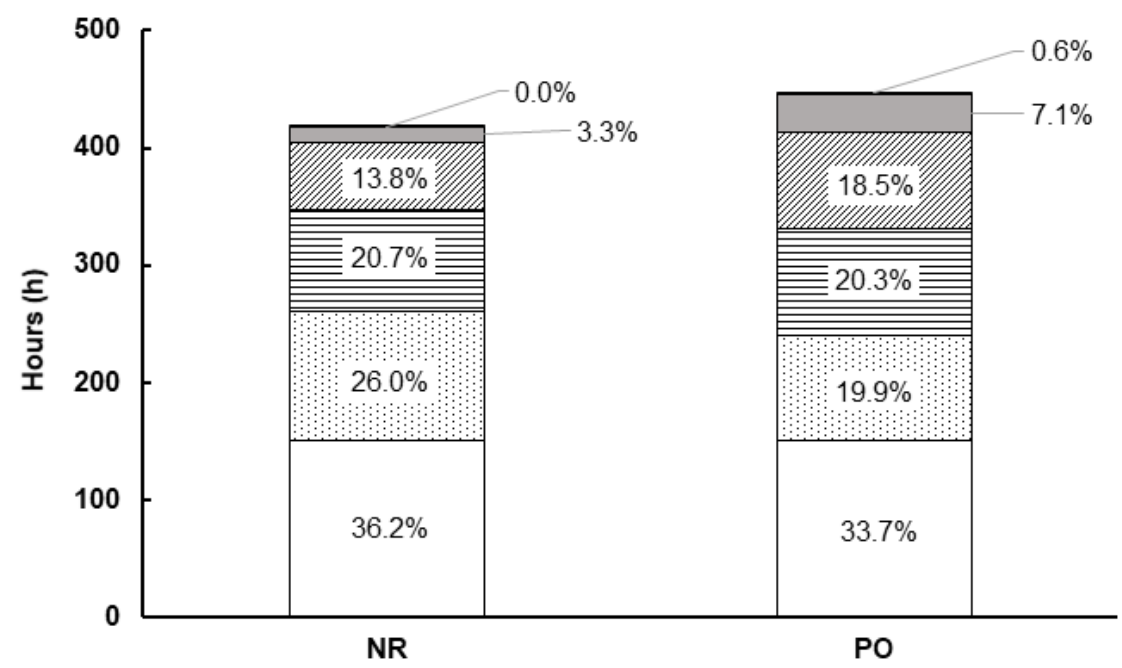

Figure 3. The cumulative hours of air temperature above $28.0^{\circ} \mathrm{C}$ and the ratio of each air temperature hour to that of cumulative hours. NR, NIR reflective film; PO, polyolefin film. Each instantaneous air temperature (recorded every minute) was categorized by every 2.0 degrees from $28.0^{\circ} \mathrm{C}$. The values in the stacked bars are the percentages of each temperature category in the total cumulative hours of air temperature above $28.0^{\circ} \mathrm{C}$. 


\subsection{Fruit Yield and Quality}

No significant differences were detected in total yield, the number of fruits, or marketable fruit yield between NR and PO (Table 1). DM content, fresh fruit weight and cracking fruit rate were significantly lower under NR compared with $\mathrm{PO}(p<0.01, p<0.05$, $p<0.01$, respectively; Table 1).

Table 1. Effects of high tunnel-covering film on total yield, number of fruits, fresh fruit weight, dry matter (DM) content, marketable fruit yield, and fruit cracking rate.

\begin{tabular}{|c|c|c|c|c|c|c|}
\hline Film & $\begin{array}{l}\text { Total Yield } \\
\left(\mathrm{kg} \mathrm{m}^{-2}\right)\end{array}$ & 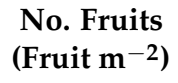 & $\begin{array}{l}\text { Fresh Fruit Weight } \\
\text { (g Fruit }^{-1} \text { ) }\end{array}$ & $\begin{array}{c}\text { DM Content } \\
(\%)\end{array}$ & $\begin{array}{l}\text { Marketable Fruit } \\
\text { Yield }\left(\mathrm{kg} \mathrm{m}^{-2}\right)\end{array}$ & $\begin{array}{c}\text { Fruit Cracking } \\
\text { Rate }(\%)\end{array}$ \\
\hline NR & $6.0 \pm 0.3$ & $74.0 \pm 2.4$ & $80.9 \pm 3.0$ & $4.76 \pm 0.03$ & $3.9 \pm 0.1$ & $13.4 \pm 2.2$ \\
\hline $\mathrm{PO}$ & $6.6 \pm 0.4$ & $74.0 \pm 3.5$ & $89.6 \pm 2.7$ & $5.13 \pm 0.02$ & $3.8 \pm 0.5$ & $29.6 \pm 3.6$ \\
\hline$p$-value & 0.18 & 0.68 & $<0.05^{*}$ & $<0.01^{* *}$ & 0.87 & $<0.01^{* *}$ \\
\hline
\end{tabular}

Values are the means of eight replicates \pm SE. The $p$-values from an independent Student's $t$-test are shown Asterisks $\left({ }^{*},{ }^{* *}\right)$ indicate a significant difference between NR and PO at $p<0.05$ or $p<0.01$, respectively.

As shown in Figure 4, there was a significant positive correlation between mean daytime air temperature from flowering to harvest and the rate of fruit cracking under $\mathrm{PO}(\mathrm{r}=0.788, p<0.001)$, whereas the correlation between these factors was weak and the relationship was not significant under NR $(r=0.200, p=0.53)$.

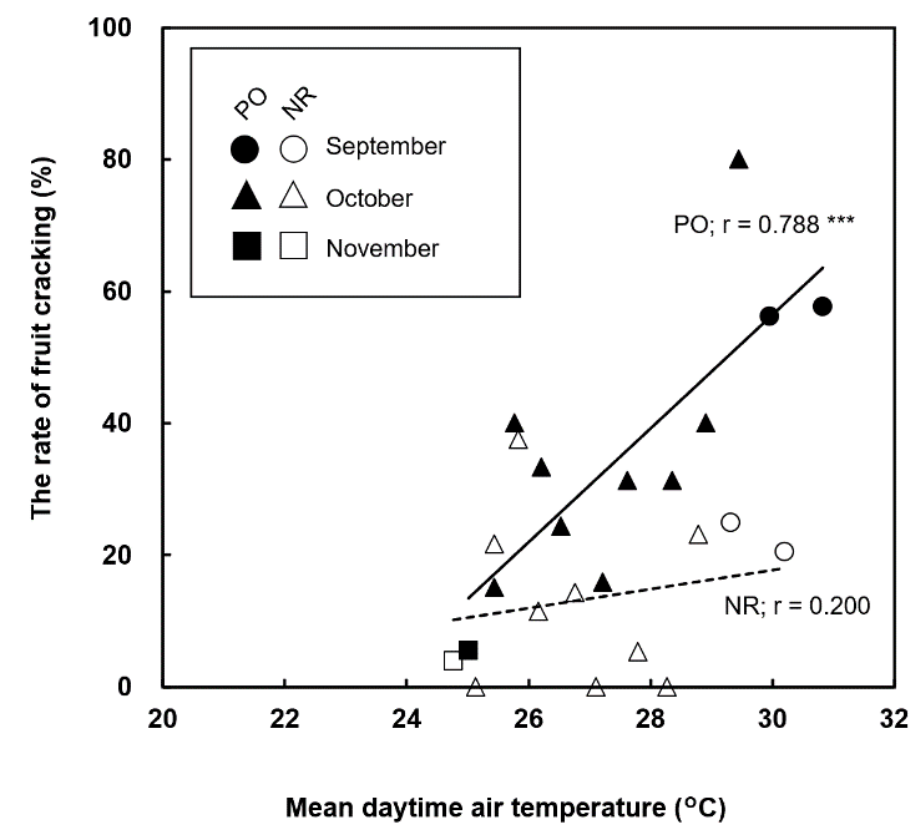

Figure 4. Pearson correlation coefficient $(\mathrm{r})$ and $p$-value between the mean daytime temperature (7 a.m. to 5 p.m.) from flowering to harvest and the rate of fruit cracking. The circles $(\bigcirc)$, triangles $(\triangle \boldsymbol{\Delta})$, and squares $(\square \mathbf{D})$ indicate the rate of fruit cracking when the tomato fruit was harvested in September, October, and November, respectively. The rate of fruit cracking was calculated as the number of cracked fruits divided by the total number of harvested fruits for each harvest date $(n=12)$. Asterisks $\left.{ }^{* * *}\right)$ indicate significant correlation at $p<0.001$.

Fruit temperatures in the first to third trusses were significantly lower under NR compared with $\mathrm{PO}(p<0.05)$, whereas that of the fourth truss tended to be lower, although this difference was not statistically significant ( $p=0.06$; Figure 5$)$. The difference in fruit temperature increased with truss number. It was $1.6^{\circ} \mathrm{C}$ in the first truss, $2.1^{\circ} \mathrm{C}$ in the second truss, $2.9^{\circ} \mathrm{C}$ in the third truss and $4.8^{\circ} \mathrm{C}$ in the fourth truss. 


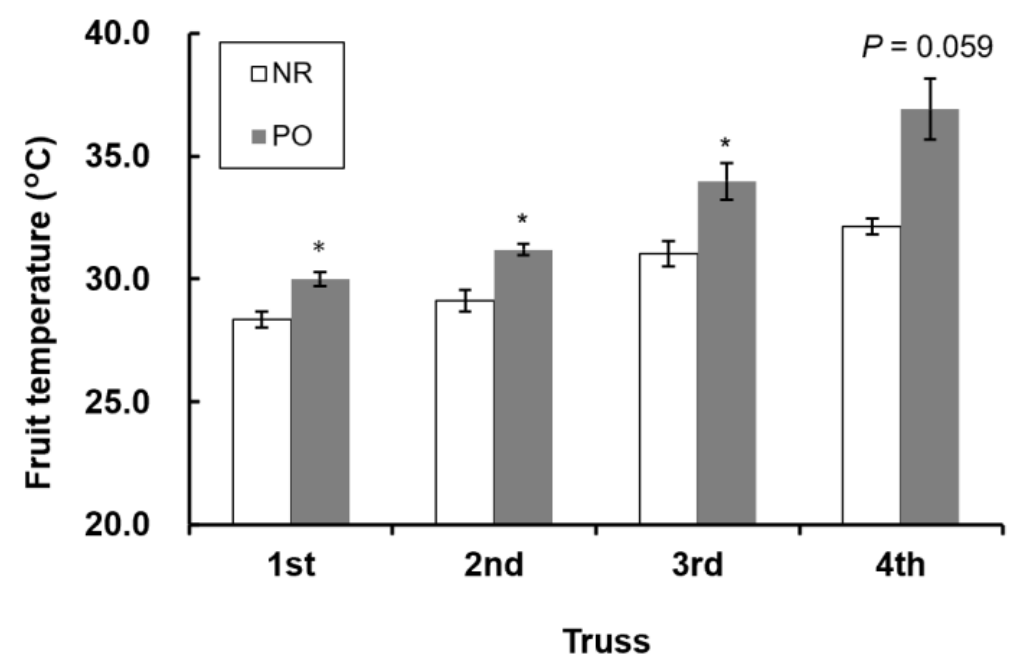

Figure 5. Fruit temperature of the first to fourth trusses of tomatoes grown in high tunnels covered with NR or PO. Mean values at each truss number from three plants \pm SE are shown. * Significantly different from PO, as determined by an independent Student's $t$-test: $p<0.05$.

On the measurement day of fruit temperature (52 DAT), the shading screen did not operate in PO. The air temperature in this high tunnel reached $30^{\circ} \mathrm{C}$ at around $8 \mathrm{a} . \mathrm{m}$. and was maintained until 3 p.m. (Figure 6). In NR, the air temperature increased gradually and reached $30^{\circ} \mathrm{C}$ at approximately 2 p.m. (Figure 6).

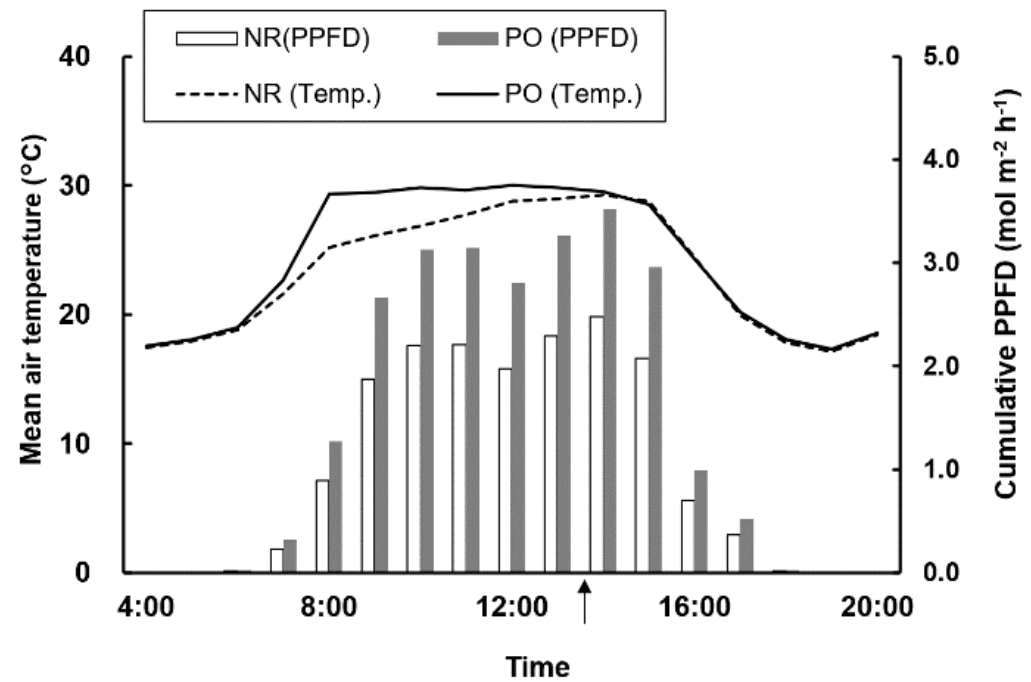

Figure 6. Daily change in microclimate in the high tunnels covered with NR or PO at 52 DAT. The arrow below the $X$-axis indicates the time of fruit temperature measurement.

\subsection{Plant Growth and Leaf Properties}

TDM was significantly lower under NR compared with PO at 42 and 92 DAT (both $p<0.01$; Table 2). No significant difference was detected in DM allocation to the organs (Table 2) or in the number of leaves (data not shown).

For plants between 0 and 42 DAT, the CGR was slightly, but significantly, lower $(p<0.01)$ and the NAR tended to be lower $(p=0.08)$ under NR, compared with PO, whereas the LAI was not significantly different. For plants between 42 and 92 DAT, the CGR $(p<0.01)$, NAR $(p<0.01)$, and LAI $(p<0.05)$ were significantly lower under NR, compared with PO (Table 3).

Total N and chl content per leaf area were significantly lower under NR (both $p<0.01$ ), but no significant difference was observed in the chl a/b ratio (Table 4). 
Table 2. Effects of high tunnel-covering film on total dry matter (TDM) and dry matter (DM) allocation to each organ at 42 and 92 DAT.

\begin{tabular}{|c|c|c|c|c|c|c|c|c|c|c|}
\hline \multirow{3}{*}{ Film } & \multicolumn{5}{|c|}{ 42DAT } & \multicolumn{5}{|c|}{ 92DAT } \\
\hline & \multirow{2}{*}{$\begin{array}{c}\text { TDM } \\
\left(\mathrm{g} \mathrm{m}^{-2}\right)\end{array}$} & \multicolumn{4}{|c|}{ DM Allocation to Each Organ (\%) } & \multirow{2}{*}{$\begin{array}{c}\text { TDM } \\
\left(\mathrm{g} \mathrm{m}^{-2}\right)\end{array}$} & \multicolumn{4}{|c|}{ DM Allocation to Each Organ (\%) } \\
\hline & & Stem & Leaves & Fruits & Others & & Stem & Leaves & Fruits & Others \\
\hline NR & $409.2 \pm 7.2$ & $30.6 \pm 0.4$ & $42.7 \pm 0.7$ & $4.7 \pm 0.2$ & $3.4 \pm 0.2$ & $720.9 \pm 26.7$ & $20.3 \pm 0.6$ & $31.9 \pm 0.6$ & $40.6 \pm 1.2$ & $7.1 \pm 0.3$ \\
\hline $\mathrm{PO}$ & $447.1 \pm 4.8$ & $31.7 \pm 0.4$ & $42.0 \pm 1.1$ & $4.7 \pm 0.3$ & $2.9 \pm 0.2$ & $891.2 \pm 21.0$ & $20.2 \pm 0.4$ & $32.0 \pm 0.5$ & $38.3 \pm 1.0$ & $9.5 \pm 0.7$ \\
\hline$p$-value & $<0.01 * *$ & 0.08 & 0.63 & 1.00 & 0.09 & $<0.01 * *$ & 0.81 & 0.88 & 0.14 & $<0.01 * *$ \\
\hline
\end{tabular}

Values are the means of eight replicates \pm SE. $p$-values from an independent Student's $t$-test are shown. Asterisks $\left.{ }^{* *}\right)$ indicate a significant difference between NR and PO at $p<0.01$.

Table 3. Effects of high tunnel-covering film on the CGR, NAR, and LAI for plants between 0 and 42 DAT and between 42 and 92 DAT.

\begin{tabular}{|c|c|c|c|c|c|c|}
\hline \multirow[b]{2}{*}{ Film } & \multicolumn{3}{|c|}{ 0-42DAT } & \multicolumn{3}{|c|}{ 42-92DAT } \\
\hline & $\begin{array}{c}\text { CGR } \\
\left(\mathrm{g} \mathrm{m}^{-2} \mathrm{Day}^{-1}\right)\end{array}$ & $\begin{array}{c}\text { NAR } \\
\left(\mathrm{g} \mathrm{m}^{-2} \mathrm{Day}^{-1}\right)\end{array}$ & $\begin{array}{c}\text { LAI } \\
\left(m^{2} m^{-2}\right)\end{array}$ & $\begin{array}{c}\text { CGR } \\
\left(\mathrm{g} \mathrm{m}^{-2} \mathrm{Day}^{-1}\right)\end{array}$ & $\begin{array}{c}\text { NAR } \\
\left(\mathrm{g} \mathrm{m}^{-2} \mathrm{Day}^{-1}\right)\end{array}$ & $\begin{array}{c}\text { LAI } \\
\left(m^{2} m^{-2}\right)\end{array}$ \\
\hline NR & $9.57 \pm 0.17$ & $6.80 \pm 0.17$ & $3.17 \pm 0.10$ & $6.11 \pm 0.52$ & $1.74 \pm 0.14$ & $3.86 \pm 0.18$ \\
\hline $\mathrm{PO}$ & $10.50 \pm 0.12$ & $7.36 \pm 0.23$ & $3.35 \pm 0.16$ & $8.71 \pm 0.41$ & $2.26 \pm 0.08$ & $4.37 \pm 0.13$ \\
\hline$p$-value & $<0.01^{* *}$ & 0.08 & 0.38 & $<0.01^{* *}$ & $<0.01^{* *}$ & $<0.05^{*}$ \\
\hline
\end{tabular}

Values are the means of eight replicates \pm SE. $p$-values from an independent Student's $t$-test are shown. Asterisks $\left({ }^{*}, * *\right)$ indicate a significant difference between NR and PO at $p<0.05$ or $p<0.01$, respectively.

Table 4. Effects of high tunnel-covering film on total nitrogen $(\mathrm{N})$ and chlorophyll (chl) content per leaf area and on the $\mathrm{chl} \mathrm{a} / \mathrm{b}$ ratio.

\begin{tabular}{|c|c|c|c|}
\hline Film & $\begin{array}{c}\text { Total N } \\
\left(\mathrm{mmol} \mathrm{m}^{-2}\right)\end{array}$ & $\begin{array}{c}\text { chl } \\
\left(\mathrm{mmol} \mathrm{m}^{-2}\right)\end{array}$ & chl $a / b$ \\
\hline NR & $87.6 \pm 1.2$ & $0.187 \pm 0.006$ & $3.19 \pm 0.05$ \\
\hline $\mathrm{PO}$ & $107.4 \pm 2.0$ & $0.229 \pm 0.006$ & $3.11 \pm 0.10$ \\
\hline$p$-value & $<0.01^{* *}$ & $<0.01^{* *}$ & 0.49 \\
\hline
\end{tabular}

Values are the means of four replicates \pm SE. $p$-values from an independent Student's $t$-test are shown. Asterisks $(* *)$ indicate a significant difference between NR and PO at $p<0.01$.

\section{Discussion}

\subsection{NIR Reflective Film Contributes to Fruit Quality}

The mean air temperature in the high tunnel was lower and the cumulative hours of air temperature above $28.0{ }^{\circ} \mathrm{C}$ were shorter under $\mathrm{NR}$, compared with that under $\mathrm{PO}$, throughout the experiment (Figures 2A and 3). However, there was a significant co-relationship between mean daytime temperature and the rate of fruit cracking under $\mathrm{PO}$, whereas there was no relationship under NR. The relative humidity was maintained above $78 \%$ under both $\mathrm{PO}$ and NR throughout the experiment, and the relative humidity in both high tunnels was controlled in almost the same range (data not shown). These results suggest that air temperature inside the greenhouse is not the only cause of the reduced rate of fruit cracking under NR.

The fruit temperature in different trusses during the afternoon was $1.6-4.8^{\circ} \mathrm{C}$ lower under NR compared with PO and these differences increased with truss number (Figure 5). Air temperature on the measurement day increased more slowly under NR and reached $30{ }^{\circ} \mathrm{C}$ almost $6 \mathrm{~h}$ after it did so under PO (Figure 6). Such a moderate increase in air and fruit temperature resulted from the suppression of a rapid rise in temperature by a lower 
transmittance of NIR radiation under NR. Lang and Düring [13] reported that a higher temperature in grape berries dramatically increased the pressure exerted by the pulp on the skin and decreased skin stiffness and strength, thus increasing the rate of fruit cracking. Similarly, for tomatoes, Corey and Tan [32] postulated that the positive pressure inside the fruit stretches the $\mathrm{CO}_{2}$-impermeable pericarp outward and increases fruit volume with increased fruit temperature. Higher fruit temperature increases fruit sink strength [33] and promotes fruit expansion [34,35]. Furthermore, Peet [14] suggested that higher soluble solids in fruit also cause an increase in fruit cracking because a higher photosynthesis rate relative to the translocation site is considered to promote rapid fruit expansion $[36,37]$. Accordingly, fruit cracking is more likely to occur at times of peak temperatures and solar radiation in the field and in high tunnels $[12,14]$. In the present study, the DM content was significantly decreased under NR. There was a positive correlation between fruit DM content and Brix (soluble solids content) [38,39]. Therefore, the reason for the reduction in fruit cracking was associated with a decrease in soluble solid content in the fruit, accompanied by decreasing DM content in the fruit. In addition, the decrease in fruit DM content under NR was associated with a decrease in the TDM, but not as the result of a difference in the DM allocation to the fruits (Table 2). In other words, the decrease in DM content in fruit under NR was accompanied by a reduction in whole-plant DM production. Furthermore, NR reduced the transmittance of UV radiation into high tunnels compared to PO (Figure 1). Kimura at al. [40] showed that tunnels covered with UV-cut film tended to reduce the incidence of fruit cracking. Overall, these results suggest that the reduction in fruit cracking under NR resulted from a decrease in fruit DM content caused by lower fruit temperature and decreased TDM, and the effects of the wavelength properties of NR.

\subsection{Changes in Plant Growth under NR}

At 42 DAT, TDM was significantly lower under NR (Table 2). The CGR is derived from NAR and LAI. The NAR is considered to represent the amount of apparent photosynthesis per plant and is known as a physiological index of whole-plant growth. For plants between 0 and 42 DAT, there were no significant differences in NAR or LAI, although NAR tended to be lower under NR (Table 3). Thus, the significant decrease in CGR under NR was caused primarily by a decrease in NAR. No differences were detected in total N content or $\mathrm{N}$ allocation to leaves and stems between the high tunnels (Table S1). At 92 DAT, TDM was also significantly lower under NR. For plants between 42 and 92 DAT, NAR, and LAI were significantly lower under NR; thus, a significant decrease in CGR was caused by a lower NAR and LAI. Total N content in the vegetative organs (leaves and stems) was significantly lower under NR (Table S1), whereas N allocation to the leaves or stems did not differ significantly. Makino et al. [41] reported that an increase in $\mathrm{N}$ allocation to leaves increased in rice grown under low light intensity. We did not observe such changes in tomatoes grown under NR; thus, these tomatoes did not show much of a compensatory response to reduced PPFD. According to Kaneko et al. [42] and Higashide [43], cumulative intercepted light positively correlates with DM production. The decrease in PAR and LAI resulted in a reduction in cumulative intercepted light, which was thought to be a factor in the decrease of TDM under NR.

To clarify the cause of decreased TDM under NR from physiological factors, we measured total $\mathrm{N}$ and chl content per leaf area. The results indicated that total $\mathrm{N}$ and chl content per leaf area were significantly decreased under NR $(p<0.01$, respectively). Total $\mathrm{N}$ content per leaf area was positively correlated with photosynthesis-related factors, such as ribuloses-1,5-bisphosphate carboxylase (Rubisco), chl, cytochrome $f$, and sucrose phosphate synthase activity [41,44]. These results suggest that the photosynthetic capacity of individual tomato leaves was lower under NR compared with that under PO. These results support the presence of physiological factors for reduced NAR under NR. Therefore, the significantly lower TDM was caused not only by the lower transmitted PPFD and LAI but also by the reduced photosynthetic capacity of individual leaves under NR. 


\section{Conclusions}

NIR reflective film suppressed the extreme increase in air and fruit temperatures in the high tunnel, and total yield did not differ between the high tunnels. Moreover, the rate of fruit cracking was reduced significantly under NR. These results suggest that the reduction in fruit cracking under NR resulted from decreased fruit DM content, caused by lower fruit temperature and decreased TDM. In contrast, TDM was decreased under NR. It was caused not only by lower transmitted PPFD and LAI but also by the reduced photosynthetic capacity of individual leaves, resulting from a decrease in both total $\mathrm{N}$ and chl content. We conclude that NIR reflective film can reduce the incidence of fruit cracking in exchange for a slight reduction in TDM.

Supplementary Materials: The following supporting information can be downloaded at: https:// www.mdpi.com/article/10.3390/horticulturae8010051/s1, Table S1: Effects of high tunnel-covering film on total nitrogen $(\mathrm{N})$ and total $\mathrm{N}$ allocation to each vegetative organ at 42 and $92 \mathrm{DAT}$. Figure S1: The difference in daily mean air temperature under NR compared to PO throughout the experiment.

Author Contributions: Conceptualization, M.I. and Y.I.; methodology, H.Y. and K.K.; formal analysis, H.Y.; investigation, H.Y., S.F., N.T., I.A., Y.W. and T.A.; resources, T.A., I.A. and Y.W.; writing-original draft preparation, H.Y.; writing—review and editing, K.K., Y.N., I.A., Y.W., T.A. and Y.I.; supervision, H.Y., Y.I., K.K. and M.I.; project administration, M.I.; funding acquisition, M.I. All authors have read and agreed to the published version of the manuscript.

Funding: This research was supported by grants from the Project of the Bio-oriented Technology Research Advancement Institution (R\&D Matching funds on the field for Knowledge Integration and innovation).

Institutional Review Board Statement: Not applicable.

Informed Consent Statement: Not applicable.

Data Availability Statement: The data that support the findings of this study are restrictions apply to the availability of these data, which were used under license for the current study, and so are not publicly available. Data are however available from the corresponding author (M.I.) upon reasonable request and with permission.

Acknowledgments: We thank T. Kurisaki and T. Nakayama for technical assistance and Y. Murakami, J. Okubo, J. Ono, N. Nakane, A. Okano, M. Yamaguchi, and T. Kunifuda for their great help in supporting the management of this project.

Conflicts of Interest: The authors declare no conflict of interest.

\section{References}

1. Faostat. 2021. Available online: https://www.fao.org/faostat/ (accessed on 17 November 2021).

2. Kinet, J.M.; Peet, M.M. 1997 Tomato. In The Physiology of Vegetable Crops; Wien, H.C., Ed.; C.A.B. International: Wallingford, UK, 1997; pp. 207-258. ISBN 9780851991467.

3. Suzuki, K. Physiological disorders and their management in greenhouse tomato cultivation at high temperatures. In Adaptation to Climate Change in Agriculture; Izumi, T., Hirata, R., Matsuda, R., Eds.; Springer: Singapore, 2019; pp. 81-96. ISBN 978-981-13-9234-4. [CrossRef]

4. Hemming, S.; Kempkes, F.; Van der Braak, N.; Dueck, T.; Marissen, N. Greenhouse cooling by NIR-reflection. Acta Hortic. 2006, 719, 97-106. [CrossRef]

5. Mutwiwa, U.N.; Von Elsner, B.; Tantau, H.J.; Max, J.F.J. Cooling naturally ventilated greenhouses in the tropics by near-infra red reflection. Acta Hortic. 2008, 801, 259-266. [CrossRef]

6. López-Marín, J.; González, A.; García-Alonso, Y.; Espí, E.; Salmerón, A.; Fontecha, A.; Real, A.I. Use of cool plastic films for greenhouse covering in Southern Spain. Acta Hortic. 2008, 801, 181-186. [CrossRef]

7. Stanghellini, C.; Dai, J.; Kempkes, F. Effect of near-infrared-radiation reflective screen materials on ventilation requirement, crop transpiration and water use efficiency of a greenhouse rose crop. Biosyst. Eng. 2011, 110, 261-271. [CrossRef]

8. Mutwiwa, U.N.; Von Elsner, B.; Tantau, H.J.; Max, J.F.J. Effects of near infrared reflection greenhouse cooling on blossom-end rot and fruit cracking in tomato (Solanum lycopersicum L.). Afr. J. Hortic. Sci. 2008, 1, 33-43.

9. Ikeda, T.; Ishigami, Y.; Goto, E. The effect of $\mathrm{CO}_{2}$ enrichment in a closed greenhouse equipped with NIR-reflecting film and EHP cooling on the yield and quality of tomato fruits during the summer season. J. Agric. Meteorol. 2020, 76, 104-110. [CrossRef] 
10. Nakayama, M.; Fujita, S.; Watanabe, Y.; Ando, T.; Isozaki, M.; Iwasaki, Y. The effect of greenhouse cultivation under a heat insulation film covering on tomato growth, yield, and fruit quality in a subtropical area. Hort. J. 2021, 90, 304-313. [CrossRef]

11. Dorais, M.; Papadopoulos, A.; Gosselin, A. Greenhouse tomato fruit quality. Hort. A Rev. 2001, 26, $239-319$.

12. Frazier, W.A.; Bowers, J.L. A report on studies of tomato fruit cracking in Maryland. Proc. Soc. Hortic. Sci. 1947, 49, $241-255$.

13. Lang, A.; Düring, H. Grape berry splitting and some mechanical properties of the skin. Vitis 1990, 29, 61-70. [CrossRef]

14. Peet, M.M. Fruit cracking in tomato. Horttechnology 1992, 2, 216-223. [CrossRef]

15. Blanchard, M.G.; Runkle, E.S. Influence of NIR-reflecting shading paint on greenhouse environment, plant temperature, and growth and flowering of bedding plants. Trans. ASABE 2010, 53, 939-944. [CrossRef]

16. Lobos, G.A.; Acevedo-Opazo, C.; Guajardo-Moreno, A.; Valdés-Gómez, H.; Taylor, J.; Laurie, V.F. Effects of kaolin-based particle film and fruit zone netting on Cabernet Sauvignon physiology and fruit quality. J. Int. Sci. Vigne Vin 2015, 49, 137-144. [CrossRef]

17. Spicher, L.; Glauser, G.; Kessler, F. Lipid antioxidant and galactolipid remodeling under temperature stress in tomato plants. Front. Plant Sci. 2016, 7, 167. [CrossRef] [PubMed]

18. Haque, M.S.; Husna, M.T.; Uddin, M.N.; Hossain, M.S.; Ali, A.K.M.G.; Abdel, O.M.; Latef, A.A.H.A.; Hossain, A. Heat Stress at Early Reproductive Stage Differentially Alters Several Physiological and Biochemical Traits of Three Tomato Cultivars. Horticulturae 2021, 7, 330. [CrossRef]

19. Pan, T.; Wang, Y.; Wang, L.; Ding, J.; Cao, Y.; Qin, G.; Yan, L.; Xi, L.; Zhang, J.; Zou, Z. Increased $\mathrm{CO}_{2}$ and light intensity regulate growth and leaf gas exchange in tomato. Physiol. Plant 2020, 168, 694-708. [CrossRef] [PubMed]

20. Heuvelink, E. Influence of day and night temperature on the growth of young tomato plants. Sci. Hortic. 1989, 38, 11-22. [CrossRef]

21. Fan, X.X.; Xu, Z.G.; Liu, X.Y.; Tang, C.M.; Wang, L.W.; Han, X.L. Effects of light intensity on the growth and leaf development of young tomato plants grown under a combination of red and blue light. Sci. Hortic. 2013, 153, 50-55. [CrossRef]

22. Gent, M.P.N. Carbohydrate level and growth of tomato plants: II. The effect of irradiance and temperature. Plant Physiol. 1986, 81, 1075-1079. [CrossRef]

23. Bruggink, G.T.; Heuvelink, E. Influence of light on the growth of young tomato, cucumber and sweet pepper plants in the greenhouse: Effects on relative growth rate, net assimilation rate and leaf area ratio. Sci. Hortic. 1987, 31, 161-174. [CrossRef]

24. Abdel-Ghany, A.M.; Al-Helal, I.M.; Alzahrani, S.M.; Alsadon, A.A.; Ali, I.M.; Elleithy, R.M. Covering materials incorporating radiation-preventing techniques to meet greenhouse cooling challenges in arid regions: A review. Sci. World J. 2012, 2012, 906360. [CrossRef] [PubMed]

25. Japan Meteorological Agency. 2020 Past Weather Data Search. Available online: https://www.jma.go.jp/jma/index.html (accessed on 19 February 2021).

26. Saeki, T. Growth analysis of plants. Shokubutsugaku Zasshi 1965, 78, 111-119. [CrossRef]

27. Watson, D.J. The dependence of net assimilation rate on leaf-area index. Ann. Bot. 1958, 22, 37-54. [CrossRef]

28. Porra, R.J.; Thompson, W.A.; Kriedemann, P.E. Determination of accurate extinction coefficients and Simultaneous equations for assaying chlorophylls a and b extracted with four different solvents: Verification of the concentration of chlorophyll standards by atomic absorption spectroscopy. Biochim. Biophys. Acta 1989, 975, 384-394. [CrossRef]

29. Yasuba, K.; Suzuki, K.; Sasaki, H.; Higashide, T.; Takaichi, M. Fruit yield and environmental condition under integrative environment control for high yielding production at long-time culture of tomato. Bull. Naro Veg. Flor. Sci. 2011, 3, 19-28. (In Japanese)

30. Hemming, S.; Kempkes, F.; van der Braak, N.; Dueck, T.; Marissen, N. Filtering natural light at the greenhouse covering-Better greenhouse climate and higher production by filtering out NIR? Acta Hortic. 2006, 711, 411-416. [CrossRef]

31. Kempkes, F.L.K.; Stanghellini, C.; Hemming, S. Cover materials excluding near infrared radiation: What is the best strategy in mild climates? Acta Hortic. 2009, 807, 67-72. [CrossRef]

32. Corey, K.A.; Tan, Z.Y. Induction of changes in internal gas pressure of bulky plant organs by temperature gradients. JASHS 1990, 115, 308-312. [CrossRef]

33. Walker, A.J.; Ho, L.C. Carbon translocation in the tomato: Carbon import and fruit growth. Ann. Bot. 1977, 41, 813-823. [CrossRef]

34. Pearce, B.D.; Grange, R.I.; Hardwick, K. The growth of young tomato fruit. I. Effects of temperature and irradiance on fruit grown in controlled environments. J. Hortic. Sci. 1993, 68, 1-11. [CrossRef]

35. Pearce, B.D.; Grange, R.I.; Hardwick, K. The growth of young tomato fruit. II. Environmental influences on glasshouse crops grown in rock wool or nutrient film. J. Hortic. Sci. 1993, 68, 13-23. [CrossRef]

36. Bakker, J.C.; Janse, J. Lage etmaaltemperatuur geeft meer kans op zwelscheuren bij tomaat. Weekbl. Groenten Fruit 1988, $26,30-31$.

37. Schilstra-van Veelen, I.M.; Bakker, J.C. Cracking of Tomato Fruits. In Annual Report 1985 Glasshouse Crops Research Station Naaldwijk; Glasshouse Crops Research Station: Naaldwijk, The Netherlands, 1985; p. 39.

38. Higashide, T.; Yasuba, K.; Suzuki, K.; Nakano, A.; Ohmori, H. Yield of Japanese tomato cultivars has been hampered by a breeding focus on flavor. HortScience 2012, 47, 1408-1411. [CrossRef]

39. Itoh, M.; Goto, C.; Iwasaki, Y.; Sugeno, W.; Ahn, D.; Higashide, T. Production of high soluble Solids fruits without reducing dry matter production in tomato plants grown in salinized nutrient solution controlled by electrical conductivity. Hort. J. 2020, 89, 403-409. [CrossRef]

40. Kimura, M.; Fujitani, S.; Itimanda, K. Mitigation techniques on fruit cracking in tomato cultivation under rain shelter in summer and autumn. Bull. Oita Pref. Agric. Forest. Fish. Res. Cent. 2012, 2, 23-42. (In Japanese) 
41. Makino, A.; Sato, T.; Nakano, H.; Mae, T.T. Leaf photosynthesis, plant growth and nitrogen allocation in rice under different irradiances. Planta 1997, 203, 390-398. Available online: https://link.springer.com/content/pdf/10.1007/s004250050205.pdf (accessed on 17 January 2021). [CrossRef]

42. Kaneko, S.; Higashide, T.; Yasuba, K.; Ohmori, H.; Nakano, A. Effects of planting stage and density of tomato seedlings on growth and yield component in low-truss cultivation. Hort. Res. 2015, 14, 163-170. (In Japanese) [CrossRef]

43. Higashide, T. Review of dry matter production and light interception by plants for yield improvement of greenhouse tomatoes in Japan. Hort. Res. (Jpn.) 2018, 17, 133-146. (In Japanese) [CrossRef]

44. Nakano, H.; Makino, A.; Mae, T. The effects of elevated partial pressures of $\mathrm{CO}_{2}$ on the relationship between photosynthetic capacity and N content in rice leaves. Plant Physiol. 1997, 115, 191-198. [CrossRef] [PubMed] 